\title{
宽坝林区珍稀濒危植物资源的初步研究 ${ }^{*}$
}

\author{
向成华 牟克华 \\ ( 四川省林业科学研究院, 成都 610081)
}

\begin{abstract}
摘 要 通过对宽坝林区珍稀濒危植物的区系分析, 得出该林区珍稀濒危植物区系具有种类较丰富, 起 源古老，区系复杂等特征。并探讨了该区珍稀濒危植物的致濒原因，提出了系列保护对策。

关键词 宽坝林区 珍稀濒危植物，区系特征保护对策

Investigation on the resources of rare and endangered plants in Kuanba forest region/Xiang Chenghua , Mou Kehua //CHINESE BIODIVERSITY. — 1997 5(3) $202 \sim 205$

Based on the floristic analysis of the rare and endangered plants ,the paper reveals that the floristic composition in Kuanba forest region has the three major characteristic features :richness in species diversity ,ancient origin and floristic complexity. The endangered causes are also discussed. The effective protected countermeasure for these species is approached.
\end{abstract}

Key words Kuanba forest region, rare and endangered plants ,folristic characteristics ,protected countermeasure

Author' s address Sichuan Research Institute of Forestry ,Chengdu ,610081

宽坝林区地处长江上游主要支流——涪江流域的平通河源头。该区的森林在涵养水源， 保持水土,稳定河川流量，维护生态平衡,保障川中盆地工农业生产等方面起着重要作用。同 时, 该区的森林又正处于青藏高原第一阶梯向四川盆地第二阶梯的过渡带上, 森林植物类型丰 富, 物种组成复杂。本文通过对宽坝林区珍稀濒危植物资源的调查研究, 旨在为该区植物区系 的组成、起源与系统演化以及珍稀濒危植物的保护和开发利用提供科学依据。

\section{1 自然概况}

宽坝林区位于四川平武县的西南缘, 东临龙门山北段西侧,南与北川县接壤, 西与松潘相 邻。地处 E $104^{\circ} 19^{\prime} 、 \mathrm{~N} 32^{\circ} 12^{\prime}$, 在纬度上属亚热带的北缘, 海拔 $1150 \sim 3260 \mathrm{~m}$ 地形为西北高， 东南低。岩石为千枚岩, 板岩等。土壤随海拔高度增加而不同, 从山簏至山顶依次为:山地黄 壤、山地黄棕壤、山地棕壤、山地棕色针叶林土壤和山地草甸土壤。年均温度为 $11{ }^{\circ} \mathrm{C}, 1$ 月份 均温为 $1{ }^{\circ} \mathrm{C}, 7$ 月份均温为 $20^{\circ} \mathrm{C}, \geqslant 10^{\circ} \mathrm{C}$ 的年积温为 $4793{ }^{\circ} \mathrm{C}$, 年降雨量为 $1187 \mathrm{~mm}$, 相对湿度 为 $88 \%$,日照时数达 691 小时。

该林区植被垂直带谱较明显。从山麓至山顶依次为山地常绿阔叶林, 山地落叶阔叶林、山 地针阔混交林，亚高山暗针叶林、亚高山草甸。

宽坝林区自然环境复杂, 植物种类较丰富。笔者从 1992 年至 1995 年对宽坝林区的植被 和植物资源进行了 4 次调查。据笔者初步统计, 该林区有高等植物 122 科,309 属,554 种。其 
中蕨类植物 16 科, 21 属, 27 种; 裸子植物 5 科, 12 属, 15 种;被子植物 101 科,276 属,512 种。

\section{2. 珍稀濒危植物资源现状}

笔者 4 次调查后初步统计, 宽坝林区珍稀濒危植物 ${ }^{[1]}$ 有 14 种 (表 1 )。这些植物一般分布 在海拔 $1150 \sim 2500 \mathrm{~m}$ 之间的山地常绿阔叶林、山地落叶阔叶林和山地针阔混交林中, 多呈零 星散生分布状态，但在海拔 $1600 \sim 1800 \mathrm{~m}$ 地带有成片珙桐林，珙桐林内有水青树，连香树等古 老子遗植物伴生。

表 1 宽坝林区珍稀濒危植物现状

Table 1 Present status of rare and endangered plants in Kuanba forest region

\begin{tabular}{|c|c|c|c|}
\hline $\begin{array}{l}\text { 类 别 } \\
\text { Category }\end{array}$ & 种 ${ }_{\text {Species }}^{\text {名 }}$ & $\begin{array}{c}\text { 保 护 级 别 } \\
\text { Protected class }\end{array}$ & $\begin{array}{l}\text { 科 名 } \\
\text { Family }\end{array}$ \\
\hline $\begin{array}{l}\text { 濒 危 } \\
\text { Endangered }\end{array}$ & 梓叶械 Acer catalpifolium Rehd. & 3 & 槭树科 Aceraceae \\
\hline $\begin{array}{l}\text { 濒 危 } \\
\text { Endangered }\end{array}$ & $\begin{array}{l}\text { 峨眉含笑 Michelia wilsonii Finet et } \\
\text { Gagnep }\end{array}$ & 2 & 木兰科 Magnoliaceae \\
\hline $\begin{array}{l}\text { 稀 }{ }^{\text {有 }} \\
\text { Rare }\end{array}$ & $\begin{array}{l}\text { 连香 树 Cercidiphyllum japonicum } \\
\text { Sieb. et Zucc }\end{array}$ & 2 & 连香树科 Cercidiphyllaceae \\
\hline $\begin{array}{l}\text { 稀 }{ }^{\text {有 }} \\
\text { Rare }\end{array}$ & 珙桐 Davidia involucrata Baillon & 1 & 蓝果树科 Nyssaceae \\
\hline $\begin{array}{l}\text { 稀 }{ }^{\text {有 }} \\
\text { Rare }\end{array}$ & 金钱棫 Dipteronia sinensis Oliv. & 3 & 械树科 Aceraceae \\
\hline $\begin{array}{l}\text { 稀 有 } \\
\text { Rare }\end{array}$ & 香果树 Emmenopterys henryi Oliv. & 2 & 茜草科 Rubiaceae \\
\hline $\begin{array}{l}\text { 稀 }{ }^{\text {有 }} \\
\text { Rare }\end{array}$ & 杜仲 Eucommia ulmoides Oliv. & 2 & 杜仲科 Eucommiaceae \\
\hline $\begin{array}{l}\text { 稀 有 } \\
\text { Rare }\end{array}$ & $\begin{array}{l}\text { 领春木 Euptelea pleiospermum Hook. } \\
\text { f. et Thoms }\end{array}$ & 3 & 昆栏树科 Trochodendraceae \\
\hline $\begin{array}{l}\text { 稀 有 } \\
\text { Rare }\end{array}$ & $\begin{array}{l}\text { 水杉 Metasequoia glyptostroboides Hu } \\
\text { et Cheng }\end{array}$ & 1 & 杉科 Taxodiaceae \\
\hline $\begin{array}{l}\text { 稀 有 } \\
\text { Rare }\end{array}$ & 水青树 Tetracentron sinense Oliv. & 2 & 木兰科 Magnoliaceae \\
\hline $\begin{array}{l}\text { 渐 危 } \\
\text { Vulnerable }\end{array}$ & 天麻 Gastrodia elata $\mathrm{Bl}$. & 3 & 兰科 Orchidaceae \\
\hline $\begin{array}{l}\text { 渐 危 } \\
\text { Vulnerable }\end{array}$ & $\begin{array}{l}\text { 厚朴 Magnolia officinalis Rehd. et } \\
\text { Wils. }\end{array}$ & 3 & 木兰科 Magnoliaceae \\
\hline $\begin{array}{l}\text { 渐 危 } \\
\text { Vulnerable }\end{array}$ & $\begin{array}{l}\text { 白辛树 Pterostyrax psilophylla Diels } \\
\text { ex Perk }\end{array}$ & 3 & 安息香科 Styraceae \\
\hline $\begin{array}{l}\text { 渐 危 } \\
\text { Vulnerable }\end{array}$ & 延龄草 Trillium tschonoskii Maxim & 3 & 百合科 Liliaceae \\
\hline
\end{tabular}

\section{3. 珍稀濒危植物的区系特征}

\section{1 种类较丰富}

宽坝林区天然保存的珍稀濒危植物已列入国家第一批重点保护 ${ }^{[1]}$ 的有 14 种 (表 1 )。从 
保护级别和保护类别看，一、二、三级植物分别有 $2 、 5 、 7$ 种, 濒危、稀有、渐危植物分别有 $2 、 8 、 4$

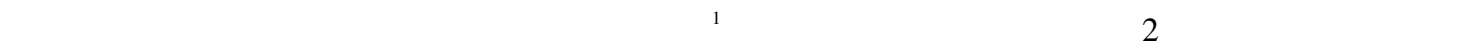
稀濒危植物较丰富。

表 2 宽坝林区珍稀濒危植物种数与四川比较

Table 2 Comparison of the rare and endangered plants in Kuanba forest region with Sichuan

\begin{tabular}{|c|c|c|c|c|c|c|c|c|}
\hline \multirow{2}{*}{ 范围 } & \multirow{2}{*}{ Region } & \multicolumn{3}{|c|}{$\begin{array}{c}\text { 保 护 级 别 } \\
\text { Protected class }\end{array}$} & \multicolumn{3}{|c|}{$\begin{array}{c}\text { 保 护 类 别 } \\
\text { Protected category }\end{array}$} & \multirow{2}{*}{$\begin{array}{l}\text { 合 计 } \\
\text { Total }\end{array}$} \\
\hline & & $\begin{array}{l}\text { 一级 } \\
\text { First }\end{array}$ & $\begin{array}{l}\text { 二级 } \\
\text { Second }\end{array}$ & $\begin{array}{l}\text { 三级 } \\
\text { Third }\end{array}$ & $\begin{array}{c}\text { 濒危 } \\
\text { Endangered }\end{array}$ & $\begin{array}{l}\text { 稀有 } \\
\text { Rare }\end{array}$ & $\begin{array}{c}\text { 渐危 } \\
\text { Vulnerable }\end{array}$ & \\
\hline 宽坝 & Kuanba & 2 & 5 & 7 & 2 & 8 & 4 & 14 \\
\hline 四川 & Sichuan & 4 & 34 & 40 & 19 & 34 & 25 & 78 \\
\hline \multicolumn{2}{|c|}{$\begin{array}{c}\text { 宽坝/四川 ( \% ) } \\
\text { KB/SC }\end{array}$} & 50.00 & 14.71 & 17.50 & 10.53 & 23.53 & 16.00 & 17.95 \\
\hline
\end{tabular}

\section{2 起源古老 ${ }^{[2,3]}$}

该林区珍稀濒危植物区系古老复杂特点主要表现在:(1) 单种科、单种属、少种属占较大 比例。单种科有连香树科的连香树、珙桐科的珙桐;单种属是分类上孤立、形态上特殊的种类， 如珙桐、香果树、连香树、杜仲、水杉等，少种属为全属仅有 $2 \sim 6$ 个种的属，一般代表古老或残 遗的类群，如领春木、金钱槭。(2) 形态上原始的类型丰富,如厚朴、峨眉含笑、连香树,领春木 等都是原始多心皮类，其中连香树、领春木等是原始无花被类型，具有很原始的无导管木质部 结构。(3) 第三纪延续和繁衍下来的植物类群丰富, 如裸子植物中的水杉, 被子植物在白严纪 初至晚期已出现的有领春木科、连香树科、械树科、木兰科等科的植物。此外还有老第三纪已 经建立的科如珙桐、杜仲。这进一步说明本区珍稀濒危植物起源的古老性。

\section{3 区系复杂 ${ }^{[3,4]}$}

该林区一些珍稀濒危植物具有温带分布属性,如金钱槭、杜仲、珙桐等。在地理分布上,领 春木科呈现偏西南分布到喜马拉雅, 呈中国-喜马拉雅分布式样, 连香树科向东偏至日本, 呈中 国-日本式分布。可见宽坝林区不仅具有中国-日本植物区系的各种成分，而且还具有中国-喜 马拉雅成分，形成了该区珍稀濒危植物区系丰富多样，成分复杂的特点。

\section{4 珍稀濒危植物致濒因素 ${ }^{[5]}$}

\section{1 采伐森林对珍稀植物的破坏}

宽坝林区是平武县的重点木材生产基地, 近 10 年来大面积森林被采伐, 珍稀濒危植物也 遭到严重破坏。一方面由于林区的伐木工都是从农村招聘来的文化程度较低的农民,这些农 民伐木时把一些高大的珍稀乔木树种 (如峨眉含笑、领春木、白辛树等) 错误地当作用材树种 砍伐掉，其幼苗、幼树也被践踏或被伐倒木损伤。另一方面，由于大面积森林被采伐，自然植被 遭受严重破坏,生态环境恶化，一些树种 (如领春木、香果树等) 生长发育和天然更新受到一定 的限制，其植株数量急剧减少。

\section{2 过分的采收利用}

这方面在对药用植物的采挖上表现为更严重。如当地农民对该林区内的杜仲、厚朴等树 种过度剥皮和对天麻、延龄草等过量挖掘,致使其植株数量目趋缩减。 
由于珍稀濒危植物本身生物学特性的限制, 使其种群数量日趋稀少。如连香树、峨眉含笑 结实率低, 香果树种子萌发力低, 白辛树开花有间歇期, 开花后又常因花梗与花萼之间有关节、 落花较多, 种子萌发力不强, 天然更新困难。

\section{5 珍稀濒危植物的保护对策}

\section{1 建立森林禁伐区}

在该林区虽然建立自然保护区有困难，但是可以建立森林禁伐区。如在该林区海拔 1600 １800 $\mathrm{m}$ 珙桐分布集中地带，选择有代表性植物群落，建立森林禁伐区，恢复和保护其生态环 境, 促进其生长发育。

\section{2 禁止砍伐, 就地保护}

采取有效措施，既要禁止砍伐珍稀濒危树种，又要杜绝对杜仲、厚朴等树种过度剥皮，还要 对峨眉含笑、梓叶槭、香果树、水青树等母树挂牌就地保护。

\section{3 采用人工种植 增加资源数量}

在该林区，既可以对水青树、白辛树、香果树、峨眉含笑等树种开展采种育苗造林，扩大种 植面积, 又可以对天麻、杜仲、厚朴等经济价值高的药用植物进行大面积人工种植增加资源数 量，提高当地居民的经济收入，以减轻当地居民为保护珍稀濒危植物所减少的经济压力。

5.4 加强宣传教育, 以求得共识

这是保护措施发挥应用作用的基础, 通过广泛宣传,让人们认识珍稀濒危植物保护的意 义,使全社会重视、理解、支持和参与保护工作。

\section{参 考 文 献}

1 国家环境保护局, 中国科学院植物所编著. 中国珍稀濒危保护植物名录 (第一册). 北京: 科学出版社, $1991,77 \sim 80$

2 四川植被协作组编著. 四川植被. 成都:四川人民出版社, 1980 50 54

3 卧龙自然保护区管理局, 南充师范学院生物系等编著. 卧龙植被及资源植物. 成都: 四川科学技术出版 社, 1987, 13 23

4 中国科学院《中国自然地理》编辑委员会. 中国自然地理一一植物地理 (上册). 北京 科学出版社, 1985, $29 \sim 92$

2 傅立国等. 中国植物红皮书——稀有濒危植物 (第一册). 北京 科学出版社, 1991 